\title{
Herbicide indirectly reduces physiological condition of a benthic grazer
}

\author{
M. Rybicki ${ }^{1, *}$, C. Winkelmann' ${ }^{2}$ C. Hellmann ${ }^{2}$, P. Bartels ${ }^{3}$, D. Jungmann ${ }^{1}$ \\ ${ }^{1}$ Institute of Hydrobiology, Technische Universität Dresden, Zellescher Weg 40, 01217 Dresden, Germany \\ ${ }^{2}$ Department of Biology, University Koblenz-Landau, Universitätsstrasse 1, 56070 Koblenz, Germany \\ ${ }^{3}$ Helmholtz Centre for Environmental Research - UFZ, Department River Ecology, Brückstrasse 3a, 39114 Magdeburg, Germany
}

\begin{abstract}
Freshwater ecosystems are polluted with various environmental chemicals. For example, pesticides enter the aquatic environment via spray drift or surface runoff from catchment areas used for industrialised agriculture. In the present study, we investigated the response of the grazer-aufwuchs interaction when exposed to the herbicide terbutryn in a microcosm experiment. Terbutryn induced a trophic cascade with negative effects on grazers by inhibiting growth of primary producers. We determined a no-observed-effect concentration (measured as particulate organic carbon, NOEC $\mathrm{POC}_{\mathrm{PO}}$ ) of $0.21 \mu \mathrm{g} \mathrm{l^{-1 }}$ for aufwuchs biomass and a lowest-observed-effect concentration $\left(\mathrm{LOEC}_{\mathrm{POC}}\right.$ ) of $2.01 \mu \mathrm{g} \mathrm{l^{-1 }}$. Furthermore, a shift in the aufwuchs community was detected in all terbutryn treatments nearly $4 \mathrm{wk}$ after exposure, and this shift persisted until the end of the experiment in the treatment with the highest terbutryn concentration. In addition, reduced energy stores (triglycerides, TG) of the grazer Rhithrogena semicolorata (Heptageniidae: Ephemeroptera) were found $\left(\mathrm{NOEC}_{\mathrm{TG}}=0.03 \mu \mathrm{g} \mathrm{l}^{-1}, \mathrm{LOEC}_{\mathrm{TG}}=0.21 \mu \mathrm{gl}^{-1}\right.$ ), which was interpreted as an indication of moderate starvation during the experiment. While starvation did not result in reduced larval growth as might have been expected, the observed reduction of TG content in larvae $(24 \%)$ is consistent with results from a separate experiment in which starvation alone induced a $15 \%$ reduction of TG content as well as reduced emergence, reduced size at emergence, and reduced egg production.
\end{abstract}

KEY WORDS: Benthic grazing $\cdot$ Indirect effects $\cdot$ Herbicide $\cdot$ Mayfly $\cdot$ Rhithrogena semicolorata Physiological condition · Fecundity

\section{INTRODUCTION}

Several regular monitoring programs and various scientific studies have demonstrated that running water ecosystems in Europe are polluted with environmental chemicals (Loague et al. 1998, Arndt-Dietrich 2002, ARGE 2004, Quednow \& Püttmann 2007, Schäfer et al. 2007). In this context, pesticides are of special concern because of their high biological effectiveness and their massive use in crop protection in industrial agriculture. Once they enter the aquatic environment, pesticides can cause direct toxic effects on non-target organisms, which vary with intensity and duration of exposure (Fleeger et al. 2003). Moreover, indirect effects on organisms in adjacent trophic levels may occur via bottom-up or top-down trophic cascades (Fleeger et al. 2003, Relyea \& Hoverman 2006). However, within the risk assessment of pesticides, indirect effects are only included in the effect analysis of higher tier studies, which are only performed when a risk for the environment has been revealed on the basis of acute and chronic toxicity (SANCO-3268 2002). In these higher tier studies, indirect effects in terms of changes in organism abundance are mainly detected, whereas more subtle indirect effects often remain undetected. Furthermore, the majority of higher tier studies are performed in lentic systems (ca. 66\%; Relyea \& Hoverman 2006), 
while pollution due to non-point sources mainly occurs into lotic ecosystems (Loague et al. 1998). Hence, we assume that the role of indirect effects, especially in running water ecosystems, is not sufficiently investigated and considered in the current risk assessment of pesticides. In the present study, we evaluated direct and indirect effects of herbicide exposure in running water ecosystems on the grazeraufwuchs interaction, using the herbicide terbutryn as a model substance.

Indirect effects of herbicides, such as reduced population growth or survival of herbivores, have been shown (Dewey 1986, Jüttner et al. 1995, Rohr \& Crumrine 2005, Mohr et al. 2007). Indirect effects of terbutryn have been shown for the macrophytebased food web of slow flowing canals, where it indirectly changed the structure of the benthic invertebrate community by altering the macrophyte community (Hanbury et al. 1981). Moreover, Brust et al. (2001) showed that terbutryn is able to induce a trophic cascade in a detritus-based food web. Inhibition of aufwuchs growth, which was the main source of detritus, significantly reduced the population growth of the detritus consumer Lumbriculus variegatus. Effects on the aufwuchs-based food web itself have not yet been investigated and are the focus of this study.

Benthic aufwuchs consists of different algae, which are the main primary producers in upper regions of running waters. In these environments, physical conditions do not allow the growth of macrophytes or phytoplankton (Allan \& Castillo 2007). Therefore, autochthonous production of aufwuchs can be the major energy source in streams. High productivity of aufwuchs occurs especially in stretches with open canopy or in spring before foliation of the riparian vegetation (Sumner \& Fisher 1979, Hill et al. 2001, Allan \& Castillo 2007). In addition, aufwuchs is a high quality food source for aquatic herbivores in streams, due to its protein and lipid richness as well as its vulnerability to grazing (Gregory 1983, Allan \& Castillo 2007). Insect larvae such as mayflies or caddisflies are major consumers of aufwuchs and play an important role in its control (Gregory 1983, Jacoby 1987, Feminella \& Hawkins 1995, Anderson et al. 1999, Hillebrand \& Kahlert 2002). Heptageniidae (Ephemeroptera) in particular are known to almost exclusively feed on aufwuchs (Mauch \& Schmedtje 1996) and are often very important grazers due to their high abundance in streams.

In the present study, we performed a microcosm experiment with aufwuchs and grazers of the mayfly Rhithrogena semicolorata (Heptageniidae: Ephemero- ptera), which were exposed to the herbicide terbutryn (single pulse). Direct impacts of terbutryn on aufwuchs as well as indirect effects on grazers were determined.

We assumed that the reduction of aufwuchs quantity by terbutryn would affect the growth and the physiological condition of grazers and aimed to deduce effect levels for indirect effects. We worked in environmentally relevant concentration ranges (ARGE 1997, Brust et al. 2001, Quednow \& Püttmann 2007) and performed a short risk assessment for terbutryn in order to determine possible effects on the environment. This was supported by a second set of experiments, in which we analysed how grazer growth, physiological condition and fecundity were influenced by reduced food supply, as could be caused by terbutryn.

\section{MATERIALS AND METHODS}

\section{Study organisms}

All organisms in this experiment were taken from a second order mountain stream located northwest of Dresden (Germany; 51 $06^{\prime} \mathrm{N}, 13^{\circ} 32^{\prime} \mathrm{E}$ ). For a detailed description of the study site see Winkelmann et al. (2008).

Mayfly Rhithrogena semicolorata larvae were used in all experiments because they belong to the scraper feeding group and feed mainly on benthic algae by scraping them from the substrate (Cummins 1973). They show a strongly synchronized univoltine life cycle with an emergence period of a few weeks from April to June (Winkelmann \& Koop 2007). Mayfly larvae were collected by kick-sampling in February and April 2005 and December 2007 for the different experiments and were kept in the laboratory in aerated glass aquaria filled with stream water at $9^{\circ} \mathrm{C}$ (2005) or $15^{\circ} \mathrm{C}(2007)$ until use.

\section{Preparation of aufwuchs}

For the terbutryn experiment, unglazed ceramic tiles $(4 \times 6 \mathrm{~cm})$ were used as substrate for the aufwuchs. To establish a stable aufwuchs biomass, tiles were placed on the bottom of a glass tank $(120 \times$ $40 \times 50 \mathrm{~cm}$ ) and covered by a $6 \mathrm{~cm}$ layer of modified Borgmann media (particle-free and activated carbonfiltered tap water with ingredients according to Borgmann 1996; LO4-S and additives E + H). Aufwuchs was obtained by scraping stones from the stream and 
collecting the scraped aufwuchs. The resulting suspension was filtered through a $250 \mu \mathrm{m}$ net, transported to the laboratory at $4^{\circ} \mathrm{C}$, shaken and then added to the prepared tank. After homogenisation by stirring, sedimentation of aufwuchs took place during the next $24 \mathrm{~h}$ in darkness. The medium was then decanted carefully using a flexible tube and a pump. The aufwuchs grew on the tiles for the next $96 \mathrm{~h}$ under a $12 \mathrm{~h}$ light: $12 \mathrm{~h}$ dark cycle without water but in high humidity (Bohle 1978). Humidity saturation was reached by placing wet paper tissues into the glass tank and closing the tank with plates. For the starvation experiments, stones with aufwuchs were taken from the stream in February and April 2005 and were directly used in the food treatments.

\section{Terbutryn}

Terbutryn (2-(tert-butylamino)-4-(ethylamino)-6(methylthio)-1,3,5-Triazin; CAS: 886-50-0) (Dr. Ehrenstorfer, $98 \%$ purity) is a synthetic herbicide of the symmetric triazine group. Terbutryn is a photosystem II inhibitor binding to the $\mathrm{Q}_{\mathrm{B}}$-binding site of the D1 protein and thus inhibiting electron transport (Trebst et al. 1991). It has a water solubility of $25 \mathrm{mg} \mathrm{l}^{-1}$, $\log$ $\mathrm{K}_{\mathrm{OW}}$ of 3.5 and is resistant to hydrolysis between pH 5 and 9. In the past, terbutryn was used as a herbicide against floating aquatic plants as well as for weed protection in agriculture. It lost approval for use in Germany on July 25th 2003 according to the European Council Directive 91/414/EEC and the European Commission Regulation (EC) 2076/2002, however, it is still in use as a biocide, i.e. as an active substance in paints, coatings, etc. Terbutryn has been found in recent years at concentrations of 0.02 to $5.6 \mathrm{ug} \mathrm{l}^{-1}$ in German surface waters (ARGE 1997, Brust et al. 2001, Quednow \& Püttmann 2007). It is used as a model herbicide in this experiment, due to the high number of studies on terbutryn and the resulting comparability to other studies.

\section{Terbutryn experiment}

The effect of terbutryn on grazer-aufwuchs interaction was analysed in a $78 \mathrm{~d}$ microcosm experiment with nominal concentrations of $0.06,0.6$ and $6 \mu \mathrm{g} \mathrm{l}{ }^{-1}$ (Treatment $0.06,0.6$ and 6 , respectively) compared to a terbutryn-free control. Aufwuchs development was monitored as particulate organic carbon (POC) to evaluate direct effects on the aufwuchs. For grazers, mortality as a lethal endpoint, as well as larval growth and physiological condition as sublethal endpoints, were quantified. The experiment consisted of a pre-application period $\left(t_{-22}\right.$ to $\left.t_{-1}\right)$ for the establishment of aufwuchs and an exposure period ( $t_{0}$ to $t_{55}$ ) with the application of terbutryn on day $\mathrm{t}_{0}$. Sampling occurred weekly during the pre-application period $\left(\mathrm{t}_{-22,-15,-8,-1}\right)$ and on $\mathrm{t}_{6,13,27,41,55}$ during the exposure period.

The experiment was performed in twelve $20 \mathrm{l}$ glass tanks $(35.5 \times 23 \times 25.5 \mathrm{~cm})$ with 3 replicates per treatment in an air-conditioned laboratory. All tanks were placed in a water bath tempered by a cooling unit (Re306, LAUDA) to ensure a constant water temperature of $8 \pm 1{ }^{\circ} \mathrm{C}$. Illumination was provided by mercury-vapour lamps (125 W, Zooga) with a $10 \mathrm{~h}$ light:14 h dark cycle and a light density of 20 to $30 \mu \mathrm{E}$ $\mathrm{m}^{-2} \mathrm{~s}^{-1}$. At the beginning of the experiment, all tanks were filled with 81 modified Borgmann media and were constantly aerated. Nutrients were added at the beginning $\left(\mathrm{t}_{-23}\right)$ of the experiment (phosphorus-P: $30 \mu \mathrm{g} \mathrm{l}^{-1}, \mathrm{Na}_{2} \mathrm{HPO}_{4}$ : $99 \%$ purity, Merck; nitrate-N: $9 \mathrm{mg} \mathrm{l}^{-1}, \mathrm{NaNO}_{3}, 99.5 \%$ purity, Merck; silicate-Si: $5 \mathrm{mg} \mathrm{l}^{-1}, \mathrm{Na}_{2} \mathrm{SiO}_{3} \cdot 5 \mathrm{H}_{2} \mathrm{O}, 97 \%$ purity, Fluka). During the pre-application period, the phosphorus concentration was adjusted at each sampling date to this level. Loss of water due to evaporation was compensated by addition of deionised water (18.2 $\mathrm{M} \Omega$, Millipore).

At $t_{-22}, 20$ tiles covered with aufwuchs were placed in each tank. The pre-application period of $3 \mathrm{wk}$ allowed the development of a stable aufwuchs biomass. Due to sampling during the pre-application period, 16 tiles remained on $\mathrm{t}_{-1}$ when 32 grazers were placed in each tank ( 2 larvae per tile, equivalent to 893 larvae per $\mathrm{m}^{2}$ ). During the exposure period 2 larvae and 1 tile per tank were removed at each sampling date to maintain constant larval density across tanks during the experiment. Dead grazers were removed immediately from the tanks and were not used for further analysis. Grazer sample size was accordingly reduced in this tank at the next regular sampling date. At the end of the experiment $\left(t_{55}\right)$, 1 tile and all remaining grazers (max. 22) were sampled.

\section{Starvation experiments}

To investigate the effects of starvation on Rhithrogena semicolorata larvae, 2 experiments were performed in February 2005 (growth experiment) and April 2005 (emergence experiment). In the growth experiment, the increase of individual dry mass of 
young larvae was monitored. In the emergence experiment, mature nymphs were used shortly before the start of their emergence to observe the effect of starvation on emergence and triglyceride content of larvae, as well as the body size and fecundity of adult females.

In both experiments, 2 treatments (control and starvation) with 3 replicates per treatment were set up in glass tanks $(25 \times 18 \mathrm{~cm})$ with aerated filtered stream water (100 $\mu \mathrm{m}$ meshes). The growth experiment was performed for $49 \mathrm{~d}\left(\mathrm{t}_{0}\right.$ to $\left.\mathrm{t}_{49}\right)$ with a temperature of $8.5 \pm 0.3^{\circ} \mathrm{C}$ and a $17 \mathrm{~h}$ light: $7 \mathrm{~h}$ dark cycle. Each tank initially contained 36 larvae of Rhithrogena semicolorata which were sampled weekly. At $\mathrm{t}_{0,} 1$ larva was sampled from each tank, 2 larvae per tank were removed each sampling date between $t_{7}$ and $t_{42}$, and 3 larvae per tank were sampled on the last day $\left(\mathrm{t}_{49}\right)$.

The $56 \mathrm{~d}$ emergence experiment was performed with an initial population of 35 larvae per tank and a water temperature of $8.9 \pm 0.6^{\circ} \mathrm{C}$. The $16 \mathrm{~h}$ light: $8 \mathrm{~h}$ dark cycle used in the experiment was similar to the natural light regime at the time of emergence at the stream site. Thereby, confounding effects of light regime on emergence behaviour were avoided. All adult mayflies that emerged during the experiment were caught by small roofs covered with closemeshed gauze placed over the tanks. The collection of adults occurred in the morning and evening of each experimental day. Therefore, no fixed sampling dates existed in this experiment, but rather individuals were caught at exactly the same point of development ( 0 to $12 \mathrm{~h}$ after emergence).

Shelter for the larvae was provided in both starvation experiments by 3 similar sized stones taken from the stream. To prevent feeding in the starvation treatment, the stones were cleaned with a brush and placed in boiling water for at least $10 \mathrm{~min}$. The stones of the control were untreated and covered with aufwuchs. Stones were changed every week in both treatments to provide a steady source of food in the food treatment and prevent growth of aufwuchs in the starvation treatment.

\section{Chemical analysis of terbutryn}

Terbutryn was applied to the tanks at $t_{0}$ of the terbutryn experiment, dissolved in $1 \mathrm{l}$ of modified Borgmann media. Hence, water volume of the tanks was increased to 91 during the process of application. The terbutryn concentration in the water was then analysed $1 \mathrm{~h}$ after application by taking $1 \mathrm{l}$ of media from the respective tank. Further samplings occurred on $t_{27}$ and $t_{55}$. On $t_{27}$, only $333 \mathrm{ml}$ of water per tank were taken and afterwards pooled within the respective treatments to reduce dilution of terbutryn in the experimental tanks due to sampling. Sample extraction, purification and addition of an internal standard are described in detail by Brust et al. (2001). Terbutryn was quantified using a gas chromatograph (GC 3800, Varian) equipped with MS/MS detection with a Varian FactorFour VF-5 ms capillary column (60 m length; $0.25 \mathrm{~mm}$ inner diameter and $0.25 \mu \mathrm{m}$ film thickness). The carrier gas was helium (5.0) with a flow rate of $1 \mathrm{ml} \mathrm{min}{ }^{-1}$. The injector operated in split/splitless mode at $250 \mathrm{C}^{\circ}$ (isothermal) and $1 \mu \mathrm{l}$ of each purified and concentrated extract was injected (CombiPAL AutoSampler, CTC Analytics). The GC oven temperature started at $90^{\circ} \mathrm{C}$ for 3 min and then increased in $12^{\circ} \mathrm{C} \mathrm{min}{ }^{-1}$ steps to $280^{\circ} \mathrm{C}$, which was held for 11.17 min resulting in a total run time of $30 \mathrm{~min}$. Terbutryn had a retention time of $19.4 \mathrm{~min}$ (quantification: 185 precursor ion $>170$ product ion at $8 \mathrm{eV}$ collision energy; verification: $226>136$ at $12 \mathrm{eV}$ ). The internal standard 2,4-dibromoaniline (purity $98 \%$, Sigma-Aldrich) was recorded at $15.7 \mathrm{~min}$ (quantification: $251>90$ at $23 \mathrm{eV}_{\text {; }}$ verification: $251>$ 170 at $17 \mathrm{eV})$. The limit of detection $\left(4 \mathrm{pg} \mathrm{pl}^{-1}\right)$ and

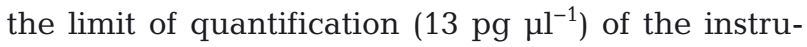
ment were calculated according to DIN 32645 (1994).

In addition to the samples, 3 standards were quantified to calculate the recovery rate of the sampling and extraction method. Hence, the final terbutryn concentrations were corrected for the determined recovery rate. The dissipation time of terbutryn was calculated using the first order kinetic reported by Brust et al. (2001) plus an additional term to account for substance losses due to regular sampling:

$$
C=c_{0} \mathrm{e}^{-k t}-\left(c_{0} \mathrm{e}^{-k t}\right) L
$$

where $C$ and $C_{0}$ are terbutryn concentrations at a specific time and at $t_{0}$, respectively, $t$ is time, $k$ is the dissipation coefficient and $L$ is percentage loss of substance at a specific time point.

\section{Analysis of physical and chemical characteristics}

Physicochemical characteristics were measured at least weekly in all experiments. Conductivity, water temperature, $\mathrm{pH}$ and oxygen concentration were measured using a Multi340i with different probes (TetraCon 325, SenTix 81 and CellOx 325, WTW). In the terbutryn experiment, the concentration of phosphorus and ammonium were determined photometrically according to the appropriate guidelines (phos- 
phorus: Legler 1976; ammonia: DIN 38406 1983). Ammonia concentration was calculated according to Hamm (1991). Concentration of nitrate was determined using anion-exchange chromatography (ISC90, Dionex) with an $8 \mathrm{mM}$ carbonate/1 mM hydrogen carbonate solution as mobile phase and an IonPac AS14A separation column (Dionex) as stationary phase.

\section{Analysis of aufwuchs}

Aufwuchs biomass was only monitored in the terbutryn experiment. It was sampled weekly until $t_{13}$ and biweekly afterwards. Each time, 1 tile per tank was sampled and aufwuchs was removed with a toothbrush and transferred to a volumetric glass flask $(50 \mathrm{ml})$. A defined volume of this suspension, 1 to $10 \mathrm{ml}$ depending on the aufwuchs amount on the tile, was filtered onto pre-ashed $\left(30 \mathrm{~min}, 500^{\circ} \mathrm{C}\right)$ glass fibre filters (MGF, $25 \mathrm{~mm}$ diameter, Sartorius). Filters were dried for $12 \mathrm{~h}\left(70^{\circ} \mathrm{C}\right.$, UM 400, Memmert) and then stored in a desiccator until analysis. The remaining aufwuchs suspension was fixed in formaldehyde $(4 \%$, purity minimum $37 \%$, Merck) and stored in $50 \mathrm{ml}$ HDPE bottles (Nalgene). The aufwuchs biomass was quantified by determination of the POC content using a carbon analyser (C-200, Leco). Aufwuchs quality was analysed at $t_{-1}, t_{27}$ and $t_{55}$ using an inverse microscope $(400 \times$, Thalheim Spezial Optik) and sedimentation chambers. Algae were counted as taxonomic groups according to the lowest practical level of determination. At least 2 transects of each sedimentation chamber were counted. The use of biovolumes was unsuitable due to the strong size variation of the algae within these groups over the experiment. Hence, we used total abundances to compare the aufwuchs community in the treatments. For the final analysis, counted groups were placed into the major algal groups (Bacillariophyta, Cyanophyta, Cholorphyta and Rhodophyta).

\section{Analysis of grazers}

For larvae, mortality, growth and physiological condition (stored energy) was determined. In the emergence experiment, the emergence success, the physiological condition of emerged specimens, as well as the body length and fecundity of the female adults were measured. The mortality was determined by counting dead individuals at the end of the experiments after correction for sampled or emerged specimens. For the analysis of growth and physiological condition, living larvae or adults were immediately frozen in liquid nitrogen after sampling and stored at $-80^{\circ} \mathrm{C}$. Larval growth was monitored over time by measuring dry weight of the larvae after $12 \mathrm{~h}$ of lyophilisation. For analysis of physiological condition, dry weight was determined (after $12 \mathrm{~h}$ lyophilisation) and triglyceride content was measured using enzymatic assays (Sigma-Aldrich; for a more detailed description see Winkelmann \& Koop 2007). In the terbutryn experiment, dry weight and triglyceride content (only the last sampling date) were analysed from the same specimen. In the emergence experiment, the triglyceride content was determined using a subsample of all emerged individuals. The body size was determined by measuring all emerged female individuals to the nearest $0.1 \mathrm{~mm}$ under a dissecting microscope from front of the head to end of abdomen. Fecundity was estimated by counting the eggs in the abdomen of all emerged females. For a detailed description of the method see Hellmann et al. (2011).

\section{Statistics}

Descriptive as well as inductive statistics were performed with the software R v.2.10 or higher (R Development Core Team 2011). Values are presented as mean $\pm \mathrm{SD}$, unless stated otherwise. Due to the temporal and spatial autocorrelation of the data in the terbutryn experiment, an analysis of differences over time was not possible. Instead, we used the overall mean for the grazer data and the area under curve (AUC) according to Purves (1992) for the aufwuchs data to compare the different treatments, because this seems to be a useful tool for data analysis in mesocosm experiments (Brust et al. 2001, Licht et al. 2003). If more than 1 data point per replicate and sampling date existed, the mean of the respective data within the replicate was used, to correct for pseudoreplication. As every treatment was always replicated 3 times, $\mathrm{n}$ was always 3 in the figures and statistical calculations. Significance of differences between treatments was tested with 1-factorial ANOVA and contrast analysis (terbutryn experiment) or Student's $t$-test (starvation experiments), after testing for inhomogeneity of variance (F-test) and normal distribution of residuals (Shapiro-Wilks normality test). To ensure high statistical power in spite of the small number of replicates, we set the value for the $\alpha$ error in the terbutryn experiment to 0.1 (Hayes 1987). The $\beta$ error $\left(E_{\beta}\right)$ was predicted with 
a power simulation to be $0.25\left(E_{\beta}=1-\right.$ power $)$ in this experiment. In the starvation experiments, we used an $\alpha$ error of 0.05 because a power test revealed an $E_{\beta}$ of $<0.001$ for all performed tests.

\section{RESULTS}

\section{Terbutryn experiment}

Determination of terbutryn standards revealed a recovery rate of $66 \%$ for the sampling and extraction method used. Considering this, the nominal concentrations of terbutryn were well established in the water tanks $1 \mathrm{~h}$ after application (Table 1). The additional analysis of terbutryn at $t_{27}$ and $t_{55}$ revealed that terbutryn dissipated continuously in all treatments, following a first order kinetic as described by Brust et al. (2001). The calculated dissipation time for $50 \%$ of the substance $\left(\mathrm{DT}_{50}\right)$ was between 18 and $22 \mathrm{~d}$ (Table 1). Effective concentrations (geometric means) of terbutryn were calculated to be $0.03 \mu \mathrm{g} \mathrm{l}^{-1}$ (Treatment 0.06), $0.21 \mathrm{gg} \mathrm{l}^{-1}$ (Treatment 0.6) and $2.01 \mu \mathrm{g} \mathrm{l^{-1 }}$ (Treatment 6).

The physicochemical characteristics measured during the exposure period showed similar values in

Table 1. Analysed terbutryn concentrations in the water phase at different sampling dates with correction for recovery rate (mean $\pm \mathrm{SD}$ ). The first sampling occurred $1 \mathrm{~h}$ after terbutryn application at the first day of the exposure period $\left(t_{0}\right.$, see Fig. 1$)$. At $t_{27}$ a pooled sample of the 3 replicates was taken. At the last day of the experiment $\left(t_{55}\right)$, again a complete sample per tank was taken. Effective concentrations and dissipation time for $50 \%$ of the terbutryn $\left(\mathrm{DT}_{50}\right)$ were calculated for the different treatments; $\mathrm{r}^{2}$ was calculated using nonlinear least squares $(\mathrm{n}=3)$

\begin{tabular}{|c|c|c|c|c|c|}
\hline \multirow{2}{*}{$\begin{array}{l}\text { Nominal } \\
\text { terbutryn conc. } \\
\left(\mu \mathrm{g}^{-1}\right)\end{array}$} & \multicolumn{3}{|c|}{ - Sampling times } & \multirow{2}{*}{$\begin{array}{c}\text { Effective } \\
\text { conc. } \\
\left(\mu \mathrm{g} \mathrm{l}^{-1}\right)\end{array}$} & \multirow{2}{*}{$\begin{array}{c}\mathrm{DT}_{50} \\
\text { (d) }\end{array}$} \\
\hline & $\begin{array}{c}t_{0} \\
(1 \mathrm{~h})\end{array}$ & $\begin{array}{c}\mathrm{t}_{27} \\
\text { (pooled) }\end{array}$ & $t_{55}$ & & \\
\hline 0.06 & $0.089 \pm 0.012$ & 0.025 & $0.013 \pm 0.002$ & 0.03 & $19.5\left(r^{2}=0.96\right)$ \\
\hline 0.6 & $0.547 \pm 0.022$ & 0.174 & $0.099 \pm 0.032$ & 0.21 & $22.3\left(r^{2}=0.98\right)$ \\
\hline 6 & $6.330 \pm 0.710$ & 1.836 & $0.700 \pm 0.060$ & 2.01 & $17.8\left(r^{2}=0.98\right)$ \\
\hline
\end{tabular}

the control and the treatments, and no significant differences were observed (Table 2).

During the pre-application period, the POC, used as an indicator for the aufwuchs development, increased in all treatments from the initial value of 0.1 to $0.3 \mathrm{mg} \mathrm{cm}^{-2}$ (Fig. 1). During this time, the mean POC content was not significantly different between the treatments (ANOVA, df $=3, F=0.67, \mathrm{p}=0.59$ ). Upon application, all treatments showed a decrease of aufwuchs biomass until $t_{27}$. After $t_{27}$, all treatments except Treatment 6 showed a dose-dependent increase in aufwuchs biomass (Fig. 1). The AUC analysis revealed a concentration response relationship with terbutryn (ANOVA, $\mathrm{df}=3, F=3.60, \mathrm{p}=0.07$, Fig. 2). However, only Treatment 6 showed a significant reduction compared to the control (contrast analysis of ANOVA, control vs. Treatment 6: $p=0.03$ ).

Microscopic analysis of aufwuchs revealed no change in the proportion of the major algal groups in the control treatment but an increase in Cyanophyta at $t_{27}$ in the terbutryn treatments. This increased proportion of Cyanophyta remained stable in Treatment 6 , but shifted back to the original proportion in the other terbutryn treatments by $t_{55}$ (Fig. 3).

The mean individual dry weight of the larvae increased in the control from $0.8 \pm 0.3 \mathrm{mg}$ at $\mathrm{t}_{6}$ to $2.2 \pm$ $0.6 \mathrm{mg}$ at the end of the experiment (Fig. 4). Regardless of the reduced aufwuchs biomass in the terbutryn treatments, all larvae grew similarly (Fig. 4), and a comparison of the mean dry weights showed no significant differences between the treatments (Table 3).

The triglyceride content of the larvae as an indicator of physiological condition showed a significant decrease depending on the terbutryn concentration (ANOVA, $\mathrm{df}=3, F=4.88, \mathrm{p}=0.03$,

Table 2. Water characteristics during the exposure period of the terbutryn experiment (mean \pm SD); SRP: soluble reactive phosphorus; b.l.q.: below limit of quantification; AN: ANOVA, KW: Kruskal-Wallis test; $\mathrm{n}=3$

\begin{tabular}{|c|c|c|c|c|c|c|c|c|}
\hline $\begin{array}{l}\text { Treatment } \\
\left(\mu \mathrm{g} \mathrm{l}^{-1}\right)\end{array}$ & $\begin{array}{c}\text { Temperature } \\
\left({ }^{\circ} \mathrm{C}\right)\end{array}$ & $\begin{array}{l}\text { Conductivity } \\
\left(\mu \mathrm{S} \mathrm{cm}^{-1}\right)\end{array}$ & $\begin{array}{c}\mathrm{O}_{2} \\
\left(\mathrm{mg} \mathrm{l}^{-1}\right)\end{array}$ & $\mathrm{pH}$ & $\begin{array}{l}\text { SRP-P } \\
\left(\mu \mathrm{g} \mathrm{l}^{-1}\right)\end{array}$ & $\underset{\left(\mu \mathrm{g} \mathrm{l}^{-1}\right)}{\operatorname{Ammonium}-\mathrm{N}}$ & $\begin{array}{c}\text { Ammonia-N } \\
\left(\mu \mathrm{g} \mathrm{l}^{-1}\right)\end{array}$ & $\begin{array}{c}\text { Nitrate-N } \\
\left(\mathrm{mg} \mathrm{l}^{-1}\right)\end{array}$ \\
\hline Control & $8.1 \pm 0.3$ & $434 \pm 14$ & $10.2 \pm 0.2$ & $7.8 \pm 0.1$ & $2.2 \pm 1.4$ & $58.7 \pm 61.8$ & $<2$ & $4.6 \pm 0.5$ \\
\hline 0.6 & $8.2 \pm 0.3$ & $430 \pm 16$ & $10.1 \pm 0.2$ & $7.8 \pm 0.1$ & $2.1 \pm 0.9$ & $27.9 \pm 33.7$ & $<2$ & $4.4 \pm 0.5$ \\
\hline 6 & $8.4 \pm 0.3$ & $435 \pm 18$ & $10.0 \pm 0.2$ & $7.8 \pm 0.1$ & $2.2 \pm 1.0$ & $46.0 \pm 55.8$ & $<2$ & $4.7 \pm 0.7$ \\
\hline Statistics & $\mathrm{AN}, \mathrm{p}=0.29$ & $\mathrm{AN}, \mathrm{p}=0.34$ & $\mathrm{AN}, \mathrm{p}=0.11$ & $\mathrm{AN}, \mathrm{p}=0.44$ & $\mathrm{AN}, \mathrm{p}=0.96$ & $\mathrm{KW}, \mathrm{p}=0.13$ & b.l.q. & $\mathrm{AN}, \mathrm{p}=0.31$ \\
\hline
\end{tabular}




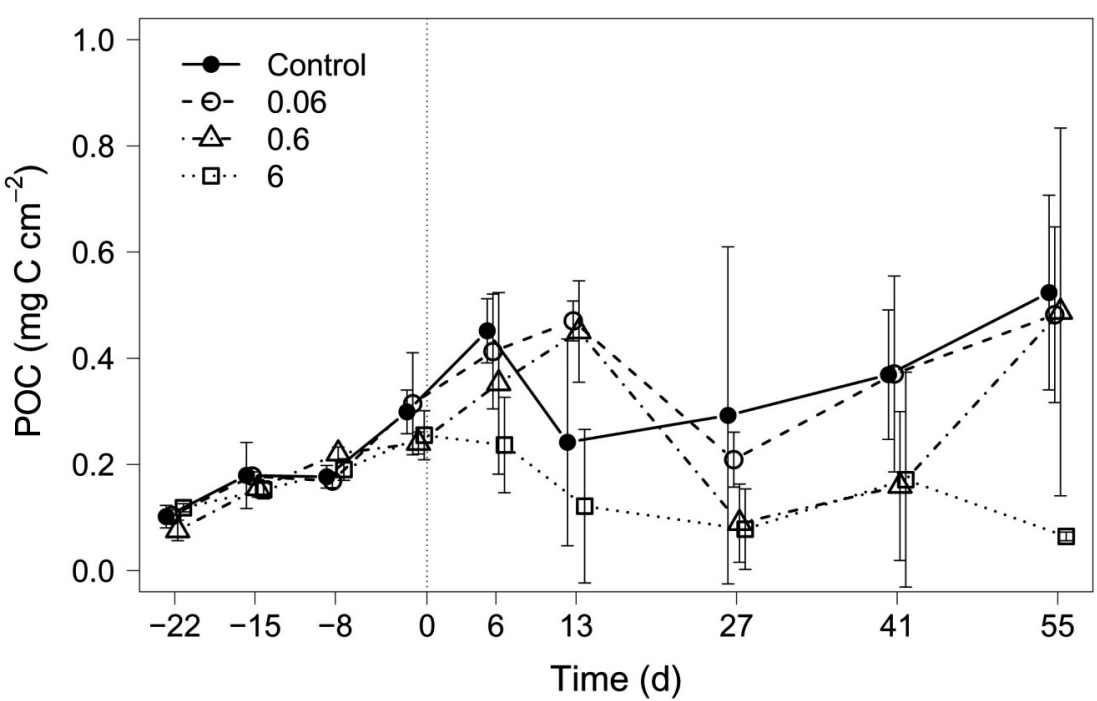

Fig. 1. Development of aufwuchs biomass (particulate organic carbon, POC) during the terbutryn experiment (mean $\pm \mathrm{SD}$ ). Data points are shifted slightly in the $x$-direction to increase visibility, but were actually taken simultaneously. $0=$ start of the exposure period $\left(t_{0}\right) ;-22$ to $-1=$ pre-application period; 0 to $55=$ exposure period; terbutryn treatments in $\mathrm{Hg} \mathrm{l}^{-1} ; \mathrm{n}=3$

Fig. 5). The mean triglyceride content of the larvae did not differ between the control and Treatment 0.06 (Fig. 5, contrast analysis of ANOVA, control vs. Treatment 0.06: $\mathrm{p}=0.77$ ), whereas larvae in Treatments 0.6 and 6 had a significantly lower triglyceride content (Fig. 5, contrast analysis of ANOVA, control vs. Treatment 0.6: $p=0.05$; control vs. $6: p=0.01$ ). The mortality of the larvae at the end of the experiment showed no response to terbutryn concentration (Table 3).

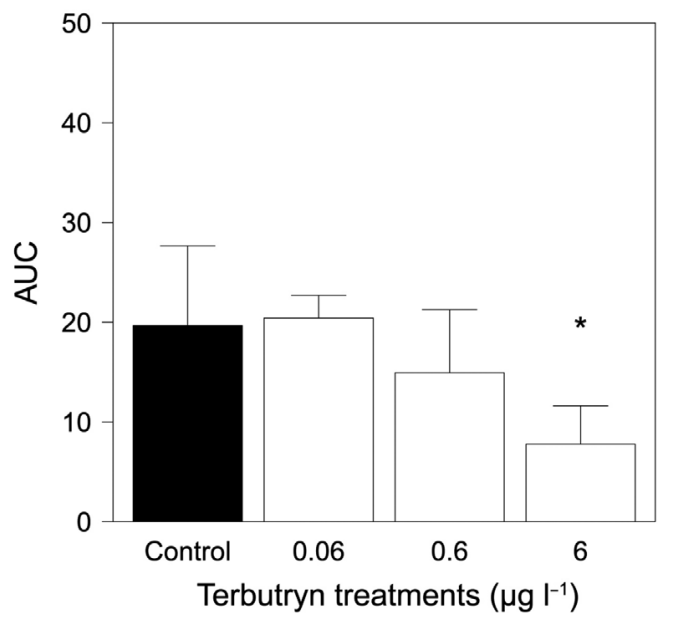

Fig. 2. Area under curve (AUC) for the POC data of the terbutryn experiment (mean $\pm \mathrm{SD}$ ). Integration started at $\mathrm{t}_{-1}$ (see Fig. 1); ${ }^{*}$ significantly different from control with $\mathrm{p} \leq 0.05 ; \mathrm{n}=3$

\section{Starvation experiments}

Starvation significantly reduced growth of young Rhithrogena semicolorata larvae (Fig. 4, Student's $t$ test, $\mathrm{df}=4, t=21.3, \mathrm{p}<0.001$ at $_{42}$ ). In the control, larvae grew about $0.07 \mathrm{mg} \mathrm{d}^{-1}$ (from $0.7 \pm 0.0$ to $3.5 \pm$ $0.2 \mathrm{mg}$ within $42 \mathrm{~d}$ ). Without food, larvae lost body mass at a rate of about $0.004 \mathrm{mg} \mathrm{d}^{-1}$. After enduring $6 \mathrm{wk}$ without any food, larvae showed a reduced dry weight of $0.5 \pm 0.1 \mathrm{mg}$. In the last week of the experiment, mortality of larvae in the starvation treatment increased dramatically; hence, no data were available at $\mathrm{t}_{49}$.

When starvation occurred in mature larvae, starting 2 wk before the first emergence, it significantly reduced the emergence success from $70 \pm 16$ to $35 \pm 12 \%$ (Fig. 6a, Student's $t$-test, df $=4, t=3.04, \mathrm{p}=0.038$ ) and the adult body length of female Rhithrogena semicolorata about $10 \%$ from $10.1 \pm 0.2$ to $8.9 \pm 0.3 \mathrm{~mm}$ (Fig. 6b, Student's $t$-test, $\mathrm{df}=4, t=5.94, \mathrm{p}=0.004)$. Furthermore, the triglycerides of emerged individuals were reduced by about $15 \%$ from $480 \pm 25$ to $409 \pm$ $10 \mu \mathrm{mol} \mathrm{g}{ }^{-1}$ dry weight (Fig. 6c, Student's $t$-test, df $=$ $4, t=4.52, \mathrm{p}=0.011$ ). Finally, a significant loss of

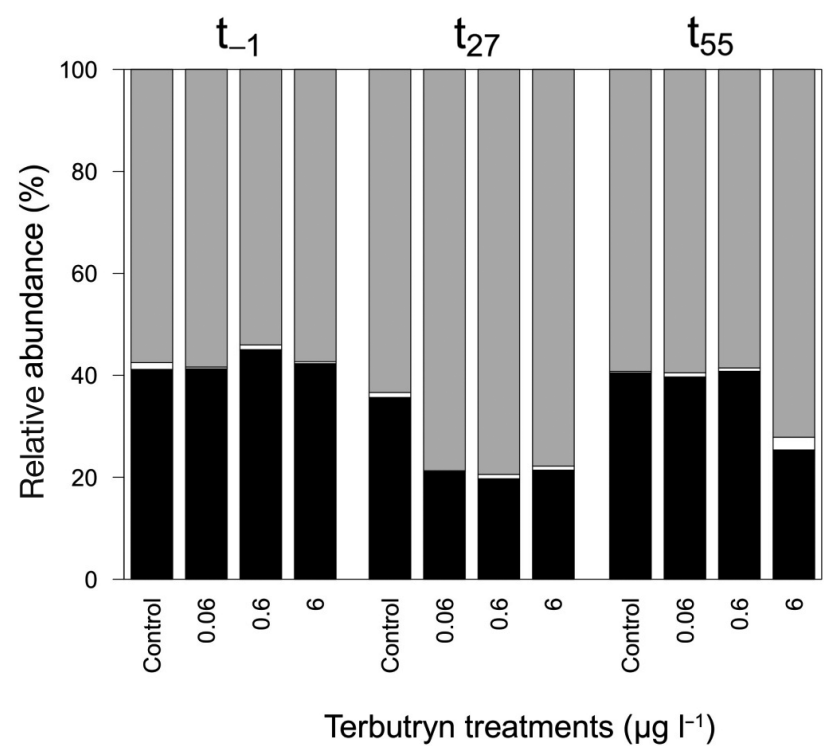

Fig. 3. Mean relative proportion of major algal groups at $t_{0}$ $t_{27}$ and $t_{55}$ (see Fig. 1) of the terbutryn experiment; grey = Cyanophyta, white $=$ Chloro- and Rhodophyta, black $=$ Bacillariophyta; $\mathrm{n}=3$ 


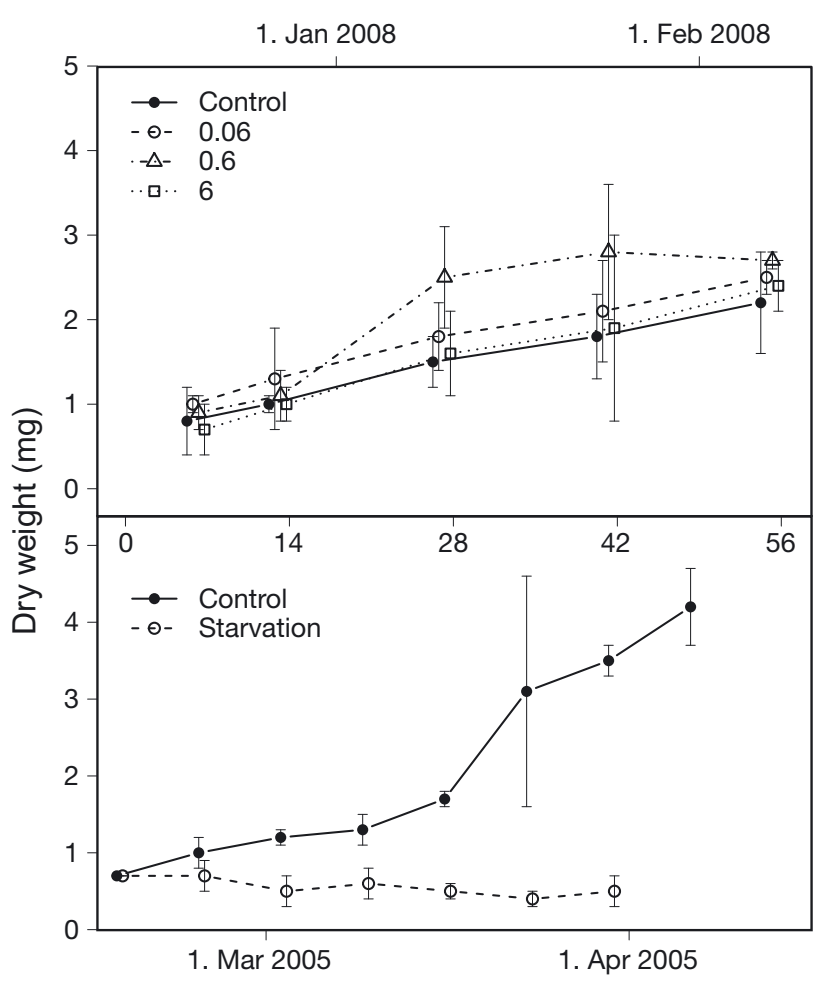

Fig. 4. Rhithrogena semicolorata. Development of larval dry weight during the exposure period of the terbutryn experiment (top), with larvae being exposed to different concentrations of terbutryn $\left(\mu \mathrm{g} \mathrm{l}^{-1}\right)$ and in the starvation experiment (bottom), with young larvae under optimal food and starvation conditions (mean $\pm \mathrm{SD}, \mathrm{n}=3$ ). Data points are shifted slightly in the $x$-direction to increase visibility, but were actually taken simultaneously. Lower and upper axis indicate the date of the experiments. The middle axis indicates the experimental time (d) of both experiments

fecundity was found, in the form of a $74 \%$ reduction of the egg numbers from $1775 \pm 74$ eggs ind. ${ }^{-1}$ in the control to $468 \pm 98$ eggs ind. ${ }^{-1}$ in the starvation treatment (Fig. 6d, Student's $t$-test, $\mathrm{df}=4, t=18.5, \mathrm{p}<$ 0.001 ). On the basis of this data, we estimated the theoretic decrease of fitness of an assumed popu-

Table 3. Rhithrogena semicolorata. Dry weight (mg) and mortality (\%) of larvae at the end of the terbutryn experiment $\left(t_{55}\right.$; see Fig. 1) (mean $\pm \mathrm{SD}$ ). Differences between treatments were tested using ANOVA $(n=3)$

\begin{tabular}{|lcc|}
\hline $\begin{array}{c}\text { Treatment } \\
\left(\mu \mathrm{g}^{-1}\right)\end{array}$ & $\begin{array}{c}\text { Dry weight } \\
(\mathrm{mg})\end{array}$ & $\begin{array}{c}\text { Mortality } \\
(\%)\end{array}$ \\
\hline Control & $2.2 \pm 0.6$ & $16.7 \pm 9.5$ \\
0.06 & $2.5 \pm 0.2$ & $18.8 \pm 8.3$ \\
0.6 & $2.7 \pm 0.1$ & $12.5 \pm 8.3$ \\
6 & $2.4 \pm 0.3$ & $8.3 \pm 1.8$ \\
Statistics & $\mathrm{df}=3, F=1.42$, & $\mathrm{df}=3, F=1.11$ \\
& $\mathrm{p}=0.31$ & $\mathrm{p}=0.40$ \\
\hline
\end{tabular}

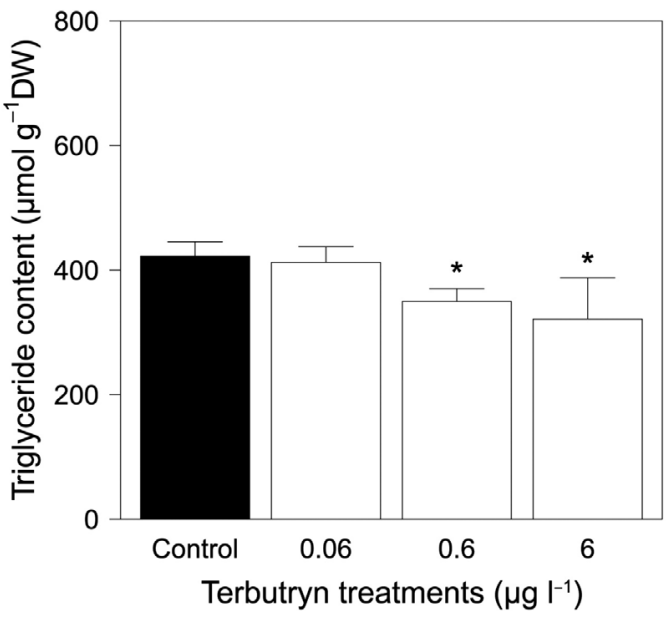

Fig. 5. Rhithrogena semicolorata. Larval triglyceride content at the end of the exposure period $\left(\mathrm{t}_{55}\right.$; see Fig. 1$)$ of the terbutryn experiment (mean $\pm \mathrm{SD})$; DW $=$ dry weight, ${ }^{*}$ significantly different from control with $\mathrm{p} \leq 0.05 ; \mathrm{n}=3$

lation to be $87 \pm 24 \%$, as a combination of the lower emergence success and the reduced fecundity (Table 4).

The physicochemical characteristics did not change during both the growth and the emergence experiments, and did not show significant differences between the food and starvation treatments (Table 5).

\section{DISCUSSION}

Freshwater ecosystems in Europe are polluted with various environmental chemicals; one of them is the herbicide terbutryn. It lost approval for use in agriculture in 2003 but it is still in use as a biocide in antifouling paints and reaches concentrations of up to $5.6 \mu \mathrm{g} \mathrm{l}^{-1}$ in German surface waters (Quednow \& Püttmann 2007). This study focussed on the aufwuchsbased food web in running water ecosystems. We hypothesised that a herbicide like terbutryn inhibits the growth of aufwuchs, which consequently results in a reduced food supply for benthic grazers. Indeed, we were able to demonstrate that terbutryn induced a trophic cascade in the aufwuchs-based food web in stream ecosystems. Direct effects of terbutryn on the aufwuchs in the form of reduced aufwuchs biomass and quality occurred at environmentally relevant concentrations $\left(\mathrm{LOEC}_{\mathrm{POC}}=2.01 \mu \mathrm{g} \mathrm{l}^{-1}\right)$. Indirect sublethal effects of terbutryn on benthic grazers, in the form of reduced triglyceride content, occurred at terbutryn concentrations which were 1 magnitude lower than those causing direct effects on the aufwuchs biomass 

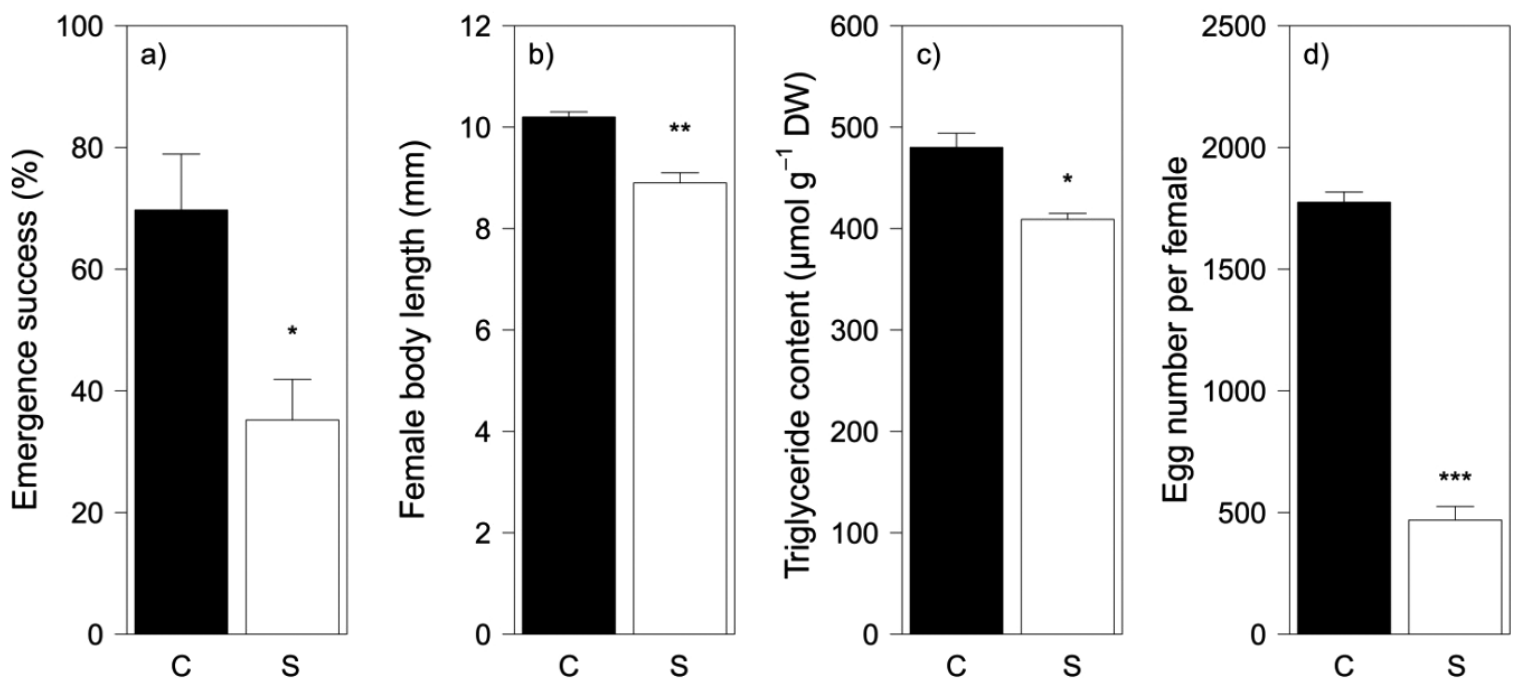

Fig. 6. Rhithrogena semicolorata. Results (mean \pm SD) of starvation experiments. (a) Emergence success of mature larvae; (b) body length of emerged female mayflies; (c) triglyceride content of emerged mayflies (both sexes); (d) number of eggs in emerged females. C: control (unlimited food); S: starvation; DW: dry weight. ${ }^{*} \mathrm{p} \leq 0.05,{ }^{* *} \mathrm{p}<0.01,{ }^{* * *} \mathrm{p}<0.001 ; \mathrm{n}=3$

Table 4. Calculated impact of starvation on the fitness of a theoretic mayfly population (mean $\pm \mathrm{SD}$ ) based on the data of the starvation experiment with mature larvae. The errors of the population fitness as well as the reduction were calculated using Gaussian error propagation

\begin{tabular}{|c|c|c|c|c|}
\hline \multirow[t]{2}{*}{ Treatment } & \multicolumn{2}{|c|}{ Females (ind. m²) } & \multirow{2}{*}{$\begin{array}{l}\text { No. eggs } \\
\text { female }^{-1}\end{array}$} & \multirow{2}{*}{$\begin{array}{c}\text { Pop. fitness } \\
\text { (total egg no. } \mathrm{m}^{-2} \text { ) }\end{array}$} \\
\hline & Larvae & Emerged & & \\
\hline Control & 100 & $70 \pm 16$ & $1775 \pm 74$ & $124250 \pm 28869$ \\
\hline Starvation & 100 & $35 \pm 12$ & $469 \pm 98$ & $16415 \pm 6591$ \\
\hline Reduction (\%) & - & $50 \pm 29$ & $74 \pm 7$ & $87 \pm 24$ \\
\hline
\end{tabular}

Table 5. Water characteristics during the 2 starvation experiments (mean $\pm \mathrm{SD}$ ); differences between the 2 treatments were tested using Student's $t$-tests $(n=3)$

\begin{tabular}{|lccccc|}
\hline Experiment & Treatment & $\begin{array}{c}\text { Temperature } \\
\left({ }^{\circ} \mathrm{C}\right)\end{array}$ & $\begin{array}{c}\text { Conductivity } \\
\left(\mu \mathrm{Cm}^{-1}\right)\end{array}$ & $\begin{array}{c}\mathrm{O}_{2} \\
\left(\mathrm{mg} \mathrm{l}^{-1}\right)\end{array}$ & $\mathrm{pH}$ \\
\hline Growth & Control & $8.6 \pm 0.2$ & $840 \pm 6$ & $9.9 \pm 0.2$ & $8.4 \pm 0.02$ \\
& Starvation & $8.3 \pm 0.3$ & $842 \pm 5$ & $10.0 \pm 0.1$ & $8.5 \pm 0.05$ \\
& $\mathrm{p}$ & 0.23 & 0.76 & 0.32 & 0.56 \\
Emergence & Control & $8.9 \pm 0.6$ & $848 \pm 6$ & $11.2 \pm 0.1$ & $8.3 \pm 0.01$ \\
& Starvation & $8.9 \pm 0.2$ & $838 \pm 3$ & $11.4 \pm 0.1$ & $8.3 \pm 0.01$ \\
& $\mathrm{p}$ & 0.89 & 0.06 & 0.07 & 0.52 \\
\hline
\end{tabular}

The magnitude of the triglyceride reduction was similar in both sets of experiments, terbutryn and emergence, which underlines the seriousness of this indirect effect of herbicides in aquatic food webs.

The characterisation of the exposure regime during the terbutryn experiment revealed that the nominal concentrations of $0.06,0.6$ and $6 \mu \mathrm{g} \mathrm{l}^{-1}$ were well reached $1 \mathrm{~h}$ after application. The calculated dissipation of terbutryn followed a first order kinetic and the calculated $\mathrm{DT}_{50}$ of 18 to $22 \mathrm{~d}$ matches with values reported in previous studies (Muir et al. 1981, Brust et al. 2001).

Terbutryn affected aufwuchs development, with a clear concentration response relationship of aufwuchs biomass with terbutryn concentration $\left(\mathrm{NOEC}_{\mathrm{POC}}\right.$

$\left(\mathrm{LOEC}_{\mathrm{TG}}=0.21 \mu \mathrm{g} \mathrm{l}^{-1}\right)$. In addition, we interpret the reduction of triglyceride content in the grazers, observed as a sublethal effect in this study, as an indicator of a potential fitness reduction. This was supported by additional starvation experiments, which revealed a dramatic reduction of female fecundity parallel to the reduction of larval growth and adult triglycerides. $=0.21 \mathrm{\mu g} \mathrm{l}^{-1}\left[0.6 \mu \mathrm{g} \mathrm{l}^{-1}\right.$ nominal $] ;$ LOEC $_{\mathrm{POC}}=2.01 \mu \mathrm{g}$ $\mathrm{l}^{-1}$ [6 $\mu \mathrm{g} \mathrm{l^{-1 }}$ nominal]). Treatment 6 showed a nearly complete removal of aufwuchs, whereas the other treatments showed increasing biomass levels with decreasing terbutryn concentrations. We assume that 2 processes influenced the aufwuchs biomass development during this experiment. Firstly, the grazing ac- 
tivity of the larvae led to a direct reduction of the aufwuchs biomass in all treatments. Secondly, the growth-inhibiting effect of terbutryn caused a concentration-dependent growth of aufwuchs or even a certain mortality of algae within the aufwuchs. This herbicidal effect of terbutryn has been shown in several former studies (Murphy et al. 1981, Goldsborough \& Robinson 1983, Struve et al. 1991, Brust et al. 2001). Therefore, we assume that terbutryn was the main inhibiting factor causing the differences in aufwuchs development between the treatments. However, the grazing activity of the larvae has to be considered as well. Beside the basic consumption of grazers in every treatment, the grazing activity of larvae can increase in order to compensate reduced quantity and/or low quality of food (Cattaneo \& Mousseau 1995). An increased feeding activity with increasing terbutryn concentration therefore might have enhanced the effects on aufwuchs biomass in the higher terbutryn concentrations and might have at least contributed to the concentration response relationship. As the grazing activity was not explicitly determined in this experiment, no discrimination between these 2 processes can be made. Nonetheless, the effect concentrations determined for terbutryn correspond well with values reported from other studies without grazers (Goldsborough \& Robinson 1983: LOEC $<10 \mu \mathrm{g} \mathrm{l}^{-1}$; Brust et al. 2001: $\mathrm{LOEC}=0.43 \mu \mathrm{g}^{-1}$ ), which supports the assumption that terbutryn caused the aufwuchs growth inhibition and the resulting concentration response relationship.

In addition to these quantitative effects, terbutryn seemed to affect aufwuchs composition, and thereby presumably reduced aufwuchs quality. All terbutryn treatments showed a relative increase in Cyanophyta. A community shift as a response to direct toxicity of a chemical is a common effect, due to the different sensitivities of the species to the substance within the community (Fent 2003). Effects of terbutryn on algal composition have also been reported previously (Goldsborough \& Robinson 1986, Gurney \& Robinson 1989), although only for lentic communities, where different species occur. Cyanophyta are often considered to be an unsuitable food source for herbivores, due to production of toxins and chemical deterrents, digestion-resistant cell walls, low unsaturated fatty acid contents and their often filamentous growth form (Gregory 1983, Müller-Navarra et al. 2000, Allan \& Castillo 2007). Therefore, we assume that a reduction in food quality, in addition to a reduction in food quantity, is possible. However, we investigated the algal composition on a simple basis and, hence, these results give only a first insight.
We assume that there was no direct toxic effect of terbutryn on the grazer Rhithrogena semicolorata, although an effect on the physiological condition of grazers, measured as triglyceride content, was found at an effective terbutryn concentration of $0.21 \mathrm{~g} \mathrm{~g}^{-1}$ (Treatment 0.6). However, terbutryn is a herbicide, which means that no toxic effects on invertebrates were intended when the product was designed. This is supported by the reported effect concentrations of terbutryn for Daphnia magna $\left(\mathrm{LC}_{50}(48 \mathrm{~h})=7.1 \mathrm{mg} \mathrm{l}^{-1}\right.$, Marchini et al. 1988) and Lumbriculus variegatus $\left(\mathrm{LC}_{50(48 \mathrm{~h})}=23.7 \mathrm{mg} \mathrm{l}^{-1}\right.$, Brust et al. 2001), which were used for comparison as no data on acute toxicity for mayfly larvae were available. Furthermore, our results did not show any concentration response of mortality to terbutryn. Nevertheless, a subtle effect of terbutryn on larval metabolism or behaviour cannot be completely excluded. For instance for fishes, which are more sensitive to terbutryn, Velisek et al. (2010) found sublethal effects in the form of different histological and biochemical endpoints starting at $4 \mu \mathrm{g} \mathrm{l^{-1 }}$. Few data are available for invertebrates regarding sublethal effects of terbutryn, but Streit \& Peter (1978) reported effects of the related 2-chloro triazine herbicide, atrazine, at levels of $2 \%$ of the $\mathrm{LC}_{50}$ after 1 mo of chronic exposure. However, the authors also observed other more obvious effects on parameters such as growth, behaviour and mortality. Thus, as no further indications of direct toxic effects of terbutryn on the grazers were observed in this experiment, an indirect effect of terbutryn on the grazers seems to be the most likely explanation for the observed reduction of triglycerides. Hence, we deduced a $\mathrm{NOEC}_{\mathrm{TG}}$ of $0.03 \mu \mathrm{g} \mathrm{l}^{-1}\left(0.06 \mu \mathrm{g} \mathrm{l}^{-1}\right.$ nominal) and a $\mathrm{LOEC}_{\mathrm{TG}}$ of $0.21 \mu \mathrm{g} \mathrm{l}^{-1}\left(0.6 \mu \mathrm{g} \mathrm{l}^{-1}\right.$ nominal) for an indirect effect of terbutryn on the physiological condition of grazers. This result underlines the high sensitivity of this endpoint to environmental changes and supports the view that it might be a good measure for subtle effects of biotic and abiotic factors in further laboratory and environmental studies (Koop et al. 2011).

Terbutryn seemed to induce food shortage but not severe starvation in this experiment. The latter would have dramatically reduced the growth rates of mayfly larvae (see growth experiment, present study, Fig. 4, Renault et al. 2002), which was not observed in the terbutryn experiment. On the other hand, an optimal food supply, as provided in the growth experiment with young larvae, might not have been achieved in the terbutryn experiment. The results of the growth experiment showed that under optimal food conditions (control treatment) grazers were able to grow much faster than they did in the terbutryn experiment. 
However, seasonal influences have to be considered when comparing both experiments. The terbutryn experiment was carried out in the winter months, whereas the growth experiment was performed in spring (see Fig. 4). Data of Winkelmann \& Koop (2007) suggest that the growth of Rhithrogena semicolorata strongly increases during March compared to the winter months, probably due to increased food availability. A similar increase of growth was observed in the growth experiment, which is not surprising considering that the food in this experiment was taken directly from the streams every week, leading to a semi-natural food supply. Considering that the terbutryn experiment started 2 mo earlier, it seems possible that grazer growth in the terbutryn experiment was not limited by the food supply, but by its earlier time point in the life cycle of $R$. semicolorata. Therefore, we assume that $R$. semicolorata larvae had an intermediate food supply during the terbutryn experiment in the control and suffered moderate starvation with increasing terbutryn concentrations, which influenced the triglyceride stores of the larvae, but not yet growth itself. This is supported by the aufwuchs biomass data from the terbutryn experiment. In Treatment 6, aufwuchs biomass was very low during the whole exposure period and thus seems to explain the low larval triglyceride contents. In Treatment 0.6 , on the other hand, the amount of aufwuchs biomass was not significantly reduced and, therefore, the reduction of triglycerides might not be completely explained by the quantitative terbutryn effects. We therefore suspect that the reduction in larval triglyceride content might be caused at least partly by the lower food quality, because low food quality has previously been shown to reduce the growth of mayfly larvae (Rosillon 1988). For the caddisfly Clistoronia magnifica, Cargill et al. (1985) even reported a direct influence of food quality on triglyceride storage. However, because a community shift in aufwuchs was also observed in Treatment 0.06 , a reduction in larval triglyceride was expected in this treatment as well. The lack of this effect cannot be completely explained yet, but it seems conceivable that it might have been compensated by the higher aufwuchs biomass, which was not affected by terbutryn in this treatment.

Unfortunately, no triglycerides were measured in the growth experiment to perform a direct comparison of starvation effects on larval triglyceride levels. Also, the direct comparison of absolute triglyceride levels between the terbutryn experiment and the emergence experiment would not be meaningful, due to the different life stages used (larvae vs. adults) and the accompanying differing triglyceride levels (Cargill et al. 1985, Servia et al. 2006, Winkelmann \& Koop 2007). However, a reduction of triglycerides of about $24 \%$ is still a clear indication of a reduced energy uptake; especially considering that triglycerides are the major energy store of mayflies and, hence, the main indicator of physiological fitness (Koop et al. 2011), as shown for Rhithrogena semicolorata, Ephemera danica (Winkelmann \& Koop 2007) and Heptagenia flava (Koop et al. 2008).

The results of our experiments indicate that terbutryn is able to induce a trophic cascade and indirectly affect the consumer level of the benthic food web in streams by reduction of aufwuchs quantity and quality. This assumption is supported by reports of similar indirect effects of terbutryn for the detritus food web (Brust et al. 2001), where terbutryn inhibited aufwuchs growth and therefore indirectly reduced the availability of detritus, leading to a reduced population growth of the detritus consumer Lumbriculus variegatus. In addition, Hanbury et al. (1981) reported a decrease in benthic invertebrate biodiversity in field experiments in slow-flowing water ways in Britain, which were caused indirectly by terbutryn effects on the local submerse flora. These indirect effects of terbutryn can be compared with density-mediated indirect effects known from population ecology (Relyea \& Hoverman 2006), and hence can be expected to cause effects of similar strength in the environment. According to the Guidance Document on Aquatic Ecotoxicology (SANCO3268 2002), a risk for the environment exists if the quotient of effect and exposure concentrations (toxicity exposure ratio, TER) passes defined trigger values. In the case of terbutryn, measured environmental concentrations up to $5.6 \mu \mathrm{g} \mathrm{l^{-1 }}$ have been detected (ARGE 1997, Quednow \& Püttmann 2007) and effect concentrations of $0.21 \mathrm{ug} \mathrm{l}^{-1}$ for a direct effect $\left(\right.$ NOEC $\left._{\mathrm{POC}}\right)$ and of $0.03 \mathrm{\mu g} \mathrm{l}^{-1}$ for an indirect effect $\left(\mathrm{NOEC}_{\mathrm{TG}}\right)$ have been deduced. The resulting TER values of 0.0375 (direct) and 0.0054 (indirect) are $<10$ and therefore indicate a certain risk for the environment (SANCO-3268 2002).

The hazard of terbutryn to the environment is thereby based on its ability to induce a bottom-up trophic cascade, which could result in starvation of primary consumers. Potential effects of starvation on the development and fitness of grazers were revealed in the 2 starvation experiments. Starvation during larval development dramatically decreased the growth rate and, after long starvation periods (>42 d), finally led to mortality. Starvation shortly before emergence dramatically reduced emergence 
success $(-50 \%)$, size at emergence $(-12 \%)$, triglyceride contents of emerged mayflies $(-15 \%)$ as well as female fecundity $(-74 \%)$, as revealed in the emergence experiment. Furthermore, starvation at this time causes a theoretical reduction in population fitness of about $87 \pm 24 \%$. Considering the overall low hatching success of some species and the high natural mortality of mayfly larvae until emergence (loss until emergence: $99.4 \%$ in Ephemerella major, Rosillon 1986; 99.8\% in Hexagenia limbata, Horst \& Marzolf 1975), such a reduction in population fitness could be devastating for population development.

Although starvation in the latter experiments was much greater compared to the moderate starvation which occurred in the terbutryn experiment, we were able to demonstrate that starvation in general poses a strong impact on grazer populations. Furthermore, the terbutryn experiment revealed that anthropogenic substances such as herbicides have the potential to induce starvation, with all consequences such as reduction of growth, energy storage and emergence success, which could finally influence even population development.

Of course, more aspects have to be taken into account for a reliable extrapolation of the observed effects; for instance, the duration of a starvation period. The starvation experiment with young larvae showed that these larvae were able to survive up to $42 \mathrm{~d}$ of starvation, indicating a rather strong resistance. A further question is the recovery of larvae after such a period. It is know from experiments, e.g. Hervant \& Renault (2002) or Calow (1975), that invertebrates increase their feeding rate after a period of starvation and perform a compensatory growth to make up for developmental deficits. In addition, the impact of alternative food sources and other processes in natural systems is still not completely investigated. Hence, further research concerning the indirect effects of pesticides, preferably in more complex experiments, seems necessary.

In conclusion, our results indicate that terbutryn poses a certain risk for the aquatic environment, because reported environmental concentrations are higher or at least in the range of the estimated effect concentrations of terbutryn and calculated TER values are $<10$ (SANCO-3268 2002). Considering that the aquatic environment in Central Europe is polluted by a complex matrix of different chemicals, direct effects of herbicides on primary producers, especially during the main application times of herbicides in autumn and spring, seem even more likely. Furthermore, indirect effects of terbutryn on grazers as non-target species can be expected, because the determined LOEC for an indirect effect $\left(\mathrm{LOEC}_{\mathrm{TG}}=\right.$ $0.21 \mathrm{\mu g} \mathrm{l}^{-1}$ ) is 1 order of magnitude lower than the measured environmental concentrations $(0.02$ to $5.6 \mathrm{\mu g} \mathrm{l}^{-1}$, ARGE Elbe 1997, Brust et al. 2001, Quednow \& Püttmann 2007). Thus, widespread sublethal effects of terbutryn and possibly other herbicides on benthic insects in stream ecosystems might occur, even if no effects on the aufwuchs biomass can be detected. Our experiments revealed again the potential hazard of herbicides in the aquatic environment, especially for non-target trophic levels. In addition, it indicates advantages of triglyceride concentration as a sensitive endpoint in ecotoxicology.

Acknowledgements. We thank G. Egerer and T. Hornick for their assistance in the laboratory, as well as the remaining staff of the Institute of Hydrobiology of the TU Dresden for discussions and comments. We also thank 2 anonymous reviewers for their constructive comments, which greatly enhanced our manuscript, and the German Research Foundation (BE 1671/14-1) for financial support. Finally, we thank S. Denecke for linguistic support.

\section{LITERATURE CITED}

Allan DJ, Castillo MM (2007) Stream ecology - structure and function of running waters. Springer, Dordrecht

Anderson E, Welch E, Jacoby J, Schimek G, Horner R (1999) Periphyton removal related to phosphorus and grazer biomass level. Freshw Biol 41:633-651

ARGE (Arbeitsgemeinschaft für die Reinhaltung der Elbe) (1997). Wassergütedaten der Elbe-Zahlentafel 1996. Wassergütestelle Elbe, Hamburg

ARGE (2004). Wassergütedaten der Elbe-Zahlentafel 2004. Gewässergütebericht 231, Hamburg

Arndt-Dietrich DI (2002) Gewässergütebericht 2001 - Nordrhein-Westfalen. Gewässergütebericht 274, Landesumweltamt Nordrhein-Westfalen, Essen

Bohle H (1978) Beziehungen zwischen dem Nahrungsangebot, der Drift und der räumlichen Verteilung bei Larven von Beatis rhodani (PICTET) (Ephemeroptera: Baetidae). Arch Hydrobiol 84:500-525

Borgmann U (1996) Systematic analysis of aqueous ion requirements of Hyalella azteca: a standard artificial medium including the essential bromide ion. Arch Environ Contam Toxicol 30:356-363

Brust K, Licht O, Hultsch V, Jungmann D, Nagel R (2001) Effects of terbutryn on aufwuchs and Lumbriculus variegatus in artificial indoor streams. Environ Toxicol Chem 20:2000-2007

> Calow P (1975) The feeding strategies of two freshwater gastropods, Ancylus fluviatilis Muell. and Planorbis contortus Linn. (Pulmonata), in terms of ingestion rates and absorption efficiencies. Oecologia 20:33-49

Cargill AS, Cummins KW, Hanson BJ, Lowry RR (1985) The role of lipids, fungi, and temperature in the nutrition of a shredder caddisfly, Clistoronia magnifica. Freshw Invertebr Biol 4:64-78

Cattaneo A, Mousseau B (1995) Empirical analysis of the removal rate of periphyton by grazers. Oecologia 103: 
$249-254$

Cummins KW (1973) Trophic relations of aquatic insects. Annu Rev Entomol 18:183-206

> Dewey SL (1986) Effects of the herbicide Atrazine on aquatic insect community structure and emergence. Ecology 67:148-162

DIN 32645 (1994) Nachweis-, Erfassungs- und Bestimmungsgrenze. Beuth, Berlin

DIN 38406 (1983) Deutsche Einheitsverfahren zur Wasser-, Abwasser- und Schlammuntersuchung: Kationen (Gruppe E) Bestimmung des Ammonium-Stickstoffs (E5). Beuth, Berlin

> Feminella JW, Hawkins CP (1995) Interactions between stream herbivores and periphyton: a quantitative analysis of past experiments. J N Am Benthol Soc 14:465-509

Fent K (2003). Ökotoxikologie. Thieme, Stuttgart

> Fleeger JW, Carman KR, Nisbet RM (2003) Indirect effects of contaminants in aquatic ecosystems. Sci Total Environ $317: 207-233$

Goldsborough LG, Robinson GGC (1983) The effect of two triazine herbicides on the productivity of freshwater marsh periphyton. Aquat Toxicol 4:95-112

Goldsborough LG, Robinson GGC (1986) Changes in periphytic algal community structure as a consequence of short herbicide exposures. Hydrobiologia 139:177-192

Gregory SV (1983) Plant-herbivore interactions in stream systems. In: Barnes JR, Minshall GW (eds) Stream ecology - application and testing of general ecological theory. Plenum Press, New York, NY, p 157-189

Gurney S, Robinson G (1989) The influence of two triazine herbicides on the productivity, biomass, and community composition of freshwater marsh periphyton. Aquat Bot $36: 1-22$

Hamm A (1991) Studie über die Wirkung und Qualitätsziele von Nährstoffen in Fließgewässern. Academia Verlag, St. Augustin

Hanbury RG, Murphy KJ, Eaton JW (1981) The ecological effects of 2-methylthiotriazine herbicides used for aquatic weed control in navigable canals. II. Effects on macroinvertebrate fauna, and general discussion. Arch Hydrobiol 91:408-426

Hayes JP (1987) The positive approach to negative results in toxicology studies. Ecotoxicol Environ Saf 14:73-77

Hellmann C, Winkelmann C, Worischka S, Benndorf J (2011) Extended larval development compensates for sublethal effects of fish predation in a mayfly population (Rhithrogena semicolorata, Ephemeroptera). Limnologica 41:256-265

Hervant F, Renault D (2002) Long-term fasting and realimentation in hypogean and epigean isopods: a proposed adaptive strategy for groundwater organisms. J Exp Biol 205:2079-2087

> Hill WR, Mulholland PJ, Marzolf ER (2001) Stream ecosystem response to forest leaf emergence in spring. Ecology 82:2306-2319

> Hillebrand H, Kahlert M (2002) Effect of grazing and water column nutrient supply on biomass and nutrient content of sediment microalgae. Aquat Bot 72:143-159

Horst TJ, Marzolf R (1975) Production ecology of burrowing mayflies in a Kansas reservoir. Verh Int Ver Theor Angew Limnol 19:3029-3038

> Jacoby J (1987) Alterations in periphyton characteristics due to grazing in a cascade foothill stream. Freshw Biol 18: 495-508

> Jüttner I, Peither A, Lay JP, Kettrup A, Ormerod SJ (1995)
An outdoor mesocosm study to assess ecotoxicological effects of Atrazine on a natural plankton community. Arch Environ Contam Toxicol 29:435-441

Koop JHE, Schäffer M, Ortmann C, Winkelmann C (2008) Towards environmental assessment of river ecosystem by analyzing energy reserves of aquatic invertebrates. Limnologica 38:378-387

> Koop JHE, Winkelmann C, Becker J, Hellmann C, Ortmann C (2011) Physiological indicators of fitness in benthic invertebrates: a useful measure for ecological health assessment and experimental ecology. Aquat Ecol 45: 547-559

Legler C (1976) Ausgewählte Methoden der Wasseruntersuchung. Band 1. Institut für Wasserwirtschaft Berlin, Jena

Licht O, Jungmann D, Nagel R (2003) Method development on aufwuchs and mayfly larvae to determine the effects of chemicals in artificial indoor streams. Fresenius Environ Bull 12:594-600

Loague K, Corwin DL, Ellsworth TR (1998) The challenge of predicting nonpoint source pollution. Environ Sci Technol 32:130A-133A

- Marchini S, Passerini L, Cesareo D, Tosato M (1988) Herbicidal triazines: acute toxicity on Daphnia, fish, and plants and analysis of its relationships with structural factors. Ecotoxicol Environ Saf 16:148-157

Mauch E, Schmedtje U (1996) Biologische Gewässeranalyse - Taxaliste der Gewässerorganismen. Bayrisches Landesamt für Wasserwirtschaft, Munich

Mohr S, Berghahn R, Feibicke M, Meinecke S and others (2007) Effects of the herbicide metazochlor on macrophytes and ecosystem function in freshwater pond and stream mesocosms. Aquat Toxicol 82:73-84

Muir DCG, Pitze M, Blouw AP, Lockhart WL (1981) Fate of terbutryn in macrophyte-free and macrophytecontaining farm ponds. Weed Res 21:59-70

Müller-Navarra DC, Brett MT, Liston AM, Goldman CR (2000) A highly unsaturated fatty acid predicts carbon transfer between primary producers and consumers. Nature 403:74-77

Murphy K, Hanbury G, Eaton J (1981) The ecological effects of 2-methylthiotriazine herbicides used for aquatic weed control in navigable canals. I. Effects on aquatic flora and water chemistry. Arch Hydrobiol 91:294-331

Purves RD (1992) Optimum numerical integration methods for estimation of area-under-the-curve (AUC) and areaunder-the-moment-curve (AUMC). J Pharmacokinet Biopharm 20:211-226

Quednow K, Püttmann W (2007) Monitoring terbutryn pollution in small rivers of Hesse, Germany. J Environ Monit 9:1337-1343

R Development Core Team (2011) R: A language and environment for statistical computing. R Foundation for Statistical Computing, Vienna

> Relyea R, Hoverman J (2006) Assessing the ecology in ecotoxicology: a review and synthesis in freshwater systems. Ecol Lett 9:1157-1171

> Renault D, Hervant F, Vernon P (2002) Comparative study of the metabolic responses during food shortage and subsequent recovery at different temperatures in the adult lesser mealworm, Alphitobius diaperinus (Coleoptera: Tenebrionidae). Physiol Entomol 27:291-301

Rohr J, Crumrine W (2005) Effects of an herbicide and an insecticide on pond community structure and processes. Ecol Appl 15:1135-1147 
Rosillon D (1986) Life cycle, growth, mortality and production of Ephemerella major Klapalek (Ephemeroptera) in a trout stream in Belgium. Freshw Biol 16:269-277

Rosillon D (1988) Food preference and relative influence of temperature and food quality on life-history characteristics of a grazing mayfly, Ephemerella-Ignita (Poda). Can J Zool 66:1474-1481

SANCO-3268 (2002) Guidance document on aquatic ecotoxicology in the context of the Directive 91/414/EEC. European Commission - Health \& Consumer Protection: Directorate E/E1 - Plant health, Brussels

Schäfer RB, Caquet T, Siimes K, Mueller R, Lagadic L, Liess $M$ (2007) Effects of pesticides on community structure and ecosystem functions in agricultural streams of three biogeographical regions in Europe. Sci Total Environ 382:272-285

Servia MJ, Heydorff M, Pery ARR, Garric J, Lagadic L (2006) Sex- and developmental stage-related changes in energy reserves in fourth-instar larvae of the midge Chironomus riparius Meigen (Diptera: Chironomidae): Implications for ecotoxicity testing. Environ Entomol 35: 865-874

Streit B, Peter HM (1978) Long-term effects of atrazine to

Editorial responsibility: Christine Paetzold, Oldendorf/Luhe, Germany selected freshwater invertebrates. Arch Hydrobiol Suppl Arb Limnol Inst Univ Konstanz 55:62-77

Struve MR, Scott JH, Bayne DR (1991) Effects of fluridone and terbutryn on phytoplankton and water-quality in isolated columns of water. J Aquat Plant Manag 29:67-76

Sumner WT, Fisher SG (1979) Periphyton production in Fort River, Massachusetts. Freshw Biol 9:205-212

Trebst A, Kluth J, Tietjen K, Draber W (1991) Molecular analysis of photosystem II inhibition. In: Frehse H (eds) Pesticide chemistry, advances in international research, development and legislation. VCH, Weinheim, p 111-120

Velisek J, Sudova E, Machova J, Svobodova Z (2010) Effects of sub-chronic exposure to terbutryn in common carp (Cyprinus carpio L.). Ecotoxicol Environ Saf 73:384-390

Winkelmann C, Koop JHE (2007) The management of metabolic energy storage during the life cycle of mayflies: a comparative field investigation of the collector-gatherer Ephemera danica and the scraper Rhithrogena semicolorata. J Comp Physiol B 177:119-128

Winkelmann C, Petzoldt T, Koop JHE, Matthaei CD, Benndorf J (2008) Benthivorous fish reduce stream invertebrate drift in a large-scale field experiment. Aquat Ecol 42:483-493

Submitted: October 27, 2011; Accepted: August 23, 2012 Proofs received from author(s): November 7, 2012 